\title{
On the Characteristics of Resentment in Political Mobilization of Competitive Election in the United States
}

\author{
$\mathrm{Li}$, Zhi \\ Institute of Political Science, School of Public administration \\ Hohai University, No.1 Xikang Road \\ Nanjing 210098, P.R. China \\ lizhihhu@163.com
}

Keywords: Competitive Election, Widespread Resentment, Political Mobilization.

\begin{abstract}
Undertakers of various public positions including the president of the United States are all selected through competitive elections, and participation of voters is the basis of the normal operation of competitive elections. Political parties of the United States usually launch political mobilization by taking advantage of widespread resentment in society, to win as many ballots as possible. In order to make the mobilization much more targeted, political parties would usually divide themselves from enemies, so as to confirm the "targets" of resentment in the political mobilization. Based on the effective demarcation, political parties would also construct contents of political mobilization through issues related to the daily lives and political symbolism, to capture the target of resentment of common voters. In conclusion, political mobilization of competitive elections in the United States features resentment, and developing countries should keep alert to the introduction of competitive election.
\end{abstract}

\section{Introduction}

Undertakers of various public positions including the president of the United States are all selected through competitive elections. Candidates would organize campaigns for competitive elections, promote themselves by publishing statements of beliefs, engaging in debates, etc. and finally achieve victory by wining the votes. The participation of voters shall be the basis of the normal operation of competitive elections. In American society, however, common people focus on private fields in lives, while the political field is of no fundamental value for them. Besides, they would participate in political activities like elections occasionally, being unenthusiastic and even indifferent to politics. The average voting rate of 26 presidential elections in the United States before 2008 was only $48 \%$, and it was much lower in other elections for public offices. [1]Therefore, to get more votes, public parties need to carry out targeted political mobilization, which mainly refers to the manipulation or abduction of the public by certain political force to reach a certain political goal. In competitive elections, which strategies are adopted by political parties in political mobilization? What are the characteristics? The above problems would be discussed in this paper.

\section{Social background of political mobilization: widespread resentment}

Resentment is an emotional experience of people when they feel the difference through comparison and develop the awareness of revenge against others. "Such an emotion contains three basic elements, namely self, others, and the distinct and biased marked value of the resentment against the latter held by the former." [2]As for the goal orientation, "resentment" is a negative emotion aiming at "others". As for the content orientation, resentment is the dissatisfaction caused after the value comparison with others. But owing to the weak strength or inappropriate occasion, others fail to take revenge immediately. Scheler insisted that resentment is "a mood in which people fail to give vent to a certain depressed emotion". [3] Such dissatisfaction would not disappear with the passage 
of time, and instead, it will last, and it is usually expressed as: I cannot forgive you, since you are not me. Such resentment pointing directly to the "essence" of others is apparently irreplaceable. [4] There is no doubt that value comparison exists in any ages, and people may become dissatisfied in comparison and turn it to resentment. But resentment is not widespread in the traditional society, for it is a society of value rank. "In such a historical period, the "position" given by god or the fate makes everyone believe that they are "settled", and they must fulfill special obligations in the position. The relations in lives are dominated by such a concept, and their sense of value and personal demands would be confined to the value of positions". [5]Since people could only compare in a small range within endowed positions, it is difficult for the widespread of resentment in the society.

The United States has been deeply rooted among the people with its founding philosophy, namely freedom and equality, and its value idea that everyone is born equal. People are inclined to pursue equality in the society, politics and morality. "People of the same nature, ability and power are born equal essentially, and are entitled to common rights and privileges". [6]Meanwhile, despite of the abundant resources and wealthy live, it cannot be denied that the United States has always been perplexed by the gap of wealth, and it is getting worse. [7]At the end of the $19^{\text {th }}$ century, $1 / 8$ of the population took up $7 / 8$ wealth of the country in 1890; but $1 \%$ of the population possessed nearly $90 \%$ of the wealth in 1896 . Compared with the end of the 19th century, $1 \%$ of the richest population possessed about 25.3 times of the wealth of the rest $99 \%$ of population in the United States in 2013. [8]In accordance with a survey report of the Wall Street Journal in September 2016, 13.5\% of the population lived in poverty, while another $18 \%$ of population just got rid of poverty in the United States. In conclusion, about $31.5 \%$ of population actually lives in poverty. In the social structure with evident wealth gap, inequality may occur in various aspects, such as power, status, education, employment, etc. Weak individuals or groups in the unequal structure usually make "boundless" comparison of general existence with the entire society, especially other strong groups. During the comparing process, the weak individuals or group would discover the huge difference from other strong groups. In front of the huge gap, people would usually accuse other strong groups morally: "if we resent the inequality, it must be caused by the inappropriate achievement of others." [9]While accusing others strongly, they would also develop the resentment.

"For those harboring resentment, they are driven by the thirsty for revenge and success, and it is even experienced as the meaning of life". Consequently, they need to relieve the resentment, while the participation in election is an approach of relieving the resentment and taking revenue. According to the concept of modern democracy, people are the owners of the country, and they are of course entitled to take part in all kinds of public affairs and express their opinions. The selection among different candidates would endow voters with a certain sense of control. Furthermore, the expression of "disapproval" against the target of resentment through votes would also enable voters to gain the joy of revenge and success. Therefore, in competitive elections, political parties are making various propositions to cater to common voters, so as to stimulate the existing resentment, since the expression of resentment has the following features: to affirm, praise and extol Party A, not because of the internal characters (reflected by the policies and guidelines in the campaign), but to deny, belittle and condemn Party B. [10]After voting, voters may relieve the resentment to a certain extent, while candidates also win the expected votes.

\section{Distinguishing from enemies in political mobilization: resenting "others"}

By focusing on the widespread resentment, political parties usually distinguish "themselves" from "others". "Themselves" of courses stand for the majority, representing the justice and the right. "Others" are the minority, representing the injustice and the wrong. By distinguishing themselves from enemies, the election competitions usually become class struggles. Lipset argued that "in any domestic system, conflicts among different groups are expressed by political parties, while political parties are basically amount to the 'media democratizing the class struggles'." [11]As early in 1828, the competition between Adams and Jackson grew to be the competition between "the public" and 
the "privileged class". With the gradual implementation of the universal suffrage in the United States, more and more poor people have access to votes, and distinguishing from enemies has always been applied in the competitive elections. To be distinguished from enemies much more clearly and effectively, candidates would shape themselves in various aspects, like the lifestyle, language style, etc. aiming to remain consistent with voters both emotionally and psychologically.

As for the sense of belonging to the community, political parties always embrace "the people", and stay away from "influential officials". In competitive elections, candidates usually regard themselves as members of the public, and their competitors as the group of "influential officials" resented by the public, so as to achieve the desired effect that "people would certainly hold different opinions if not being one of the group members", and inspire the existing resentment of voters. At the end of the $19^{\text {th }}$ century, the shaping of presidential candidates by the Democratic Party was quite typical. During the election in 1896, Blaine, the candidate of the Democratic Party was shaped as a "great civilian". Blaine once claimed in a conference that "we had the people of the country and the world as the backing, supported by the business class, the working class and hardworking people from place to place", [12] while his opponent McKinley was shaped as the agent of "the Wall Street, special interest group, privileges and the rich". In the presidential election of 2016, Trump still adopted this distinguishing method, to avoid becoming the target of resentment of voters. Therefore, although Trump was a billionaire, he attempted to express that he was with the voters, and he would confront the power of the Wall Street with them.

As for the lifestyle, political parties usually advocate "frugality", and oppose "luxury". During the elections, candidates usually highlight the frugality, aiming to gain the recognition of voters psychologically. In the meantime, competitors would be related to luxury, away from "the people". For instance, in the presidential election in 1840, candidate Harrison of the Whigs was democratized, while his opponent Van Buren was described to be aristocratic. At that time, there was even a song describing the two vividly. "Van Buren" held silver cup and drank, leaning on voguish sofa armrest, while our leader sat on a wooden bench, drinking strong wine with satisfaction." [13]In competitive elections of the United States, candidates managed to avoid being associated with luxury. For instance, in 1908, the incumbent president Theodore Roosevelt advised the candidate of the Republican Party Tuft, "no photo of playing tennis, and photos of playing golf would be destructive",[14]since the working people believed that golf was the activity of the rich. To win favor, Theodore Roosevelt suggested him "to cut with an axe"! On the contrary, if candidates neglect taboos, they may activate the existing resentment of common voters, and be taught a lesson by voters with their votes. For instance, in 1884, candidate of the Democratic Party Blain attended a luxury dinner with the rich in New York, and his competitor created a cartoon about it, which had impacted the campaign of Blain substantially. In the carton, the "glorious knight" Blain ate and drank with pot-bellied rich people, while a starved man was begging for bread with his ragged wife and children. [15]

As for the language style, being "simple", not "gorgeous" is emphasized. Since common voters especially the poor are not highly educated, and the language and vocabularies of daily use are relatively simple, but the language and vocabularies adopted by the mainstream media are quite tedious and gorgeous. Common voters are usually depressed by and even dissatisfied at the limits of their power of discourse in the media, thus develop a rebellious mood, and disdain the language used by elites. Therefore, some candidates would try to be consistent with common voters in the language style, to make them feel the kindness, thus being accepted emotionally. For example, in 2008, candidate of the Democratic Party Obama used grassroots vocabularies and simple sentences familiar to common people in all occasions, and touched common voters in repeated simple sentences and moving civilian stories in his speeches. Similarly, in 2016, candidate of the Republican Party Trump was also fond of simple words or sentences. According to the analysis, vocabularies used by Trump in presidential election speeches and debates amount to the language level of the fourth grade of primary school, which were the simplest and plainest and most understood among all candidates. [16] Thanks to the language style, Trump gained the support of the 
middle and lower class to a certain extent.

\section{Content construction of political mobilization: "imagination" of resentment}

Based on the effective division, to receive the effects of political mobilization, negative contents should be added to capture the imagination of resentment of common voters. "According to statistics, about $60 \%$ of election ads in the United States were negative from 1952 to 1982, and since the $21^{\text {st }}$ century, as high as 83 to $89 \%$ of campaign ads were inclined to bring shame on opponents." [17]These adds usually contain the moral criticism of individuals. It cannot be denied that it would label the opponents with moral corruption, set up a disgusting image among common voters, and inspire the aversion of competitors. In 2016, Hillary was labelled as dishonesty by Trump due to the lies of "Email Controversy" and "Benghazi incident".

However, to better inspire the resentment of common voters, topics of interests and cohesion would be selected. "The so-called interest means that mobilization topics always involve the realistic interests of some groups, or relate to the resource allocation, or associate with the wealth distribution. The so-called cohesion means that topics should play a cohering role, and be easily understood, accepted and supported by the public." [18]Since common voters are not familiar with nor interested in domestic and foreign fundamental policies, the macro-level policy discussion and criticism would not arouse the enthusiasm of voters. As for common voters, possible changes in daily lives may be more attractive. Therefore, the intimidation in daily lives would gather the resentment of voters much more effectively. In 1896, when the candidate of the Republican Party McKinley competed with the Democratic Party Blaine, the Republican Party asked its supporters to advocate the consequences of Blaine's victory in plain language, so that voters could perceive the intimidation. Some employers printed such words on the payroll, "if Blaine was elected, do not go back to work any more, and the factory would shut down; bankers even claimed to cancel the mortgage loan and recover the loan. [19]It turned out that it did contribute to the success of McKinley. To make the intimidation much more specific, concrete numbers would also be referred to in the mobilization. For instance, practices of the Republican party in the presidential election in 1936 were quite typical, namely to slip a piece of note into the pay packet of workers to warn them: "the laws of Roosevelt's New Deal would force you to take 1\% from your pay packet and transfer it to the government after it takes effect in January 1937. And eventually, it would be as high as $4 \%$. Make your decision on the election day on November 3! You should decide whether you wish for these changes or not." [20]

To highlight the resentment of common voters, political symbolism has also been widely applied in political mobilization. Political symbolism refers to the symbol of political significance, which can reflect specific significance and emotion through such carriers as the specific person, object, action, event, etc. In the competitive elections in the United States, "the Wall Street", equal to "the rich, and privileges", is usually used to inspire the emotions and arouse the sympathy of the audience, thus to reach the goal of stirring up the resentment. In 1932, the Democratic Party wrote a doggerel to satirize the Finance Minister Andrew Mellon and President Hoover: "Mellon pulled the whistle, Hoover rang the bell, Wall Street gave the signal and the country went to hell". [21]Due to the economic recession, the unemployment rate stayed at a high level, and the "Wall Street" as a symbol had attracted great attention in the United States. The masses expressed their dissatisfaction by occupying the "Wall Street". The two parties also made full use of the symbolic significance of the "Wall Street" during the presidential election. In 2007, the subprime mortgage crisis gave rise to severe financial crisis, and the public complained the big shots on the Wall Street. To cater to the public, Obama proposed the slogan "we cannot have a thriving Wall Street while Main Street Suffers" in the presidential election. Trump indicated in 2016 that the sky-high compensation on Wall Street was a "joke". He also promised to collect high taxes from fund managers on the Wall Street if elected.

When the "Wall Street" is opposite to "the people", its negative significance would be more specific. At the end of the $19^{\text {th }}$ century, the People's Party took advantage of the two words in the 
political mobilization during the presidential election. It claimed that "the Wall Street is in possession of the United States", "the United States is no longer a government of the people, by the people and for the people, and instead, it would become a government of the Wall Street, by the Wall Street and for the Wall Street". [22]The people's party demanded to send the government back to Americans.

\section{Conclusion}

The United States, as a leading power in the world, is always taken as the learning object of political and economic regimes by developing countries. But if developing countries introduce the competitive election mode promoted in the United States arbitrarily regardless of the practical situations, it may bring more harm, since some developing countries suffer from severe gap of wealth, and the political mobilization of competitive election would result in severer class confrontation. More importantly, many developing countries fail to reach high political consensus in the community, regime and procedures. If the competitive election is implemented, topics like the community may become seditious contents. If the resentment topic is manipulated by the political force, it would sharpen the contradictions between different groups, and cause severe political conflicts, and the community may also fall apart.

\section{Acknowledgement}

This research was financially supported by the Social Science Fund of Jiangsu Province (Grant NO.15ZZB006) and the Fundamental Research Funds for the Central Universities (Grant NO.2016B30514).

\section{References}

[1] Song Xiongwei, Looking into the Public Indifference to Elections in Western Democratic Countries [J]. Qiushi, 2012 (9): 64.

[2] [9] Wang Haizhou, Imaginary Revenge: "Resentment" in the View of Western Politics [J]. Journal of Nanjing University (Philosophy, Humanities and Social Sciences), 2007 (6): 38-47.

[3] [5] Scheler, Subversion of Value [M]. Beijing: Sanlian Bookstore, 1997:7,21

[4] Scheler, Anthology of Scheler (I) Resentment in Moral Construction [M]. Shanghai: Sanlian Bookstore, 1999: 408.

[6] Locke, Two Treatises of Civil Government (I) [M]. Beijing: Commercial Press, 1982: 56.

[7] Samuel Eliet Morrison, the Growth of the American Republic (II) [M]. P. 351-352.

[8] Estelle Sommeiller, Mark Price, and Ellis Wazeter, "Income Inequality in the U.S. by State, Metropolitan Area, and County," Economic Policy Institute Report, June 16, 2016, http: / / www. Epi.org / files / pdf /107100.pdf.

[10] Max Scheler, Resentment and Humiliation in Moral Consciousness [M]. Beijing: Beijing Normal University Press, 2014: 37.

[11] Seymour Martin Lipset. Political Man: The Social Bases of Politics [M]. Garden City, N.Y.: Anchor Books, 1963: 203.

[12] [13] [14] [15] [20] [21] [22] Boller P.F. Jr. Presidential Campaigns[M]. Changchun: Jilin University Press, 1989: 166.74.187.151. 243-244. 237.161.

[16] Li Lingling, Analysis of the Communication Strategy in the Trump Campaign [J]. Journalism Lover, 2016 (10): 50-54.

[17] Richard R. Lau, Lee Sigelman \& Ivy Brown Rovner. The Effects of Negative Political Campaigns: A Meta-Analytic Reassessment[J]. The Journal of Politics, 2007(4): 1176-1209.

[18] Kong Fanbin, Logic of Action of Political Mobilization - A Conceptual Model and Its Application [J]. The Journal of Jiangsu Administration Institute, 2006 (5): 79-84.

[19] Arthur Schlesinger Jr. History of the Democratic Party [M]. Shanghai: Shanghai People's 
Publishing House, 1977: 51. 